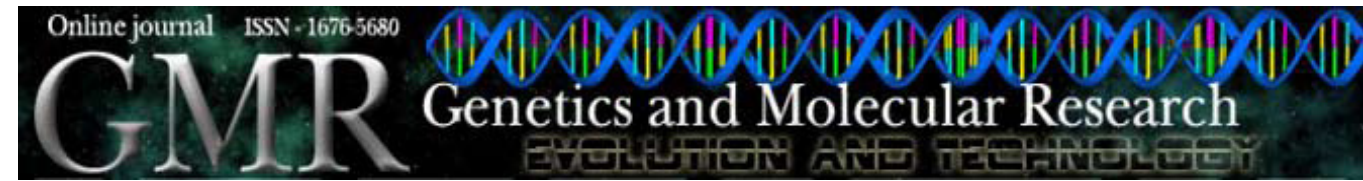

\title{
Effects of polymorphisms of LHR and FSHR genes on sexual precocity in a Bos taurus $\mathrm{x}$ Bos indicus beef composite population
}

\author{
E.P. Marson ${ }^{1}$, J.B.S. Ferraz ${ }^{2}$, F.V. Meirelles ${ }^{2}$, J.C.C. Balieiro ${ }^{2}$ \\ and J.P. Eler ${ }^{2}$ \\ ${ }^{1}$ Produção Animal, Colégio Agrícola Senador Carlos Gomes de Oliveira, \\ Universidade Federal de Santa Catarina, Araquari, SC, Brasil \\ ${ }^{2}$ Departamento de Ciências Básicas, \\ Grupo de Melhoramento Animal e Biotecnologia, \\ Faculdade de Zootecnia e Engenharia de Alimentos, \\ Universidade de São Paulo, Pirassununga, SP, Brasil \\ Corresponding author: E.P. Marson \\ E-mail: epmarson@gmail.com
}

Genet. Mol. Res. 7 (1): 243-251 (2008)

Received November 29, 2007

Accepted December 18, 2007

Published March 11, 2008

\begin{abstract}
The purpose of the present research was to investigate the effects of polymorphisms of luteinizing hormone receptor (LHR) and follicle-stimulating hormone receptor (FSHR) genes, evaluated by polymerase chain reaction-restriction fragment length polymorphism in EuropeanZebu composite beef heifers from six different breed compositions. The polymorphism site analysis from digestion with $H h a \mathrm{I}$ and $A l u \mathrm{I}$ restriction endonucleases allowed the genotype identification for LHR (TT, CT and $\mathrm{CC}$ ) and FSHR (GG, CG and CC) genes. A high frequency of heterozygous animals was recorded in all breed compositions for both genes, except in two compositions for LHR. The probability of pregnancy (PP) at first breeding was used to evaluate the polymorphism effect on sexual precocity. The PP was analyzed as a binary trait, with a value of 1 (success) assigned to heifers that were diagnosed pregnant by rectal palpation and a value of 0 (failure) assigned to those that were not pregnant at that time. Heterozygous heifers showed a higher pregnancy rate (67 and 66\% for LHR and FSHR genes, respectively), but no significant effects were observed for the genes studied $(\mathrm{P}=0.9188$ and 0.8831 for LHR and FSHR,
\end{abstract}


respectively) on the PP. These results do not justify the inclusion of LHR and FSHR restriction fragment length polymorphism markers in selection programs for sexual precocity in beef heifers. Nevertheless, these markers make possible the genotype characterization and may be used in additional studies to evaluate the genetic structure in other bovine populations.

Key words: Luteinizing hormone receptor; Composite heifers; Follicle-stimulating hormone receptor; Sexual precocity; Restriction fragment length polymorphism

\section{INTRODUCTION}

Composite bovines originate from the miscegenation of several breeds, of both Bos indicus and Bos taurus. The goal in a composite population is to keep as much heterozygosity as possible. Nowadays, this breeding scheme is expanding in Brazil, resulting from an evolution of crossbreeding systems, seeking to exploit crossbred animals to obtain heterosis effects and breed complementarity regarding economically important traits.

Many researchers have had success when demonstrating the genetic features of populations and when identifying the important genes for the determination of these features of interest in cattle production, using molecular biology techniques that employ various molecular markers, such as microsatellites and restriction fragment length polymorphisms (RFLP) (Tambasco et al., 2000; Milazzotto, 2001; Campagnari, 2002; Marson et al., 2005).

The precocious event of puberty in beef heifers is desirable in production systems since, as some other indicators of reproductive efficiency, sexual precocity is one of the requirements to be examined in promoting productivity. Hess (2002) emphasized that heifers must reach the puberty between one and three months before being introduced in the breeding site, to improve their chances of conception. Due to this fact and added to the existence of a moderate to high inheritability for this trait ( 0.31 for Laster et al., $1979 ; 0.47$ for Splan et al., 1998), sexual precocity must be adopted as a criterion of selection in beef heifer production systems.

In view of the lack of studies about the gene polymorphisms linked to reproductive characteristics in beef cattle, such as sexual precocity and the possibility that composite populations can offer for the exploitation of heterozygosity, the objective of the present research was to estimate the effects of RFLPs in the luteinizing hormone receptor (LHR) and folliclestimulating hormone receptor (FSHR) genes regarding sexual precocity in composite European-Zebu heifers, from several different breed compositions, using as a characteristic marker of this event the probability of pregnancy for heifers at first breeding.

\section{MATERIAL AND METHODS}

\section{Animals}

Blood samples for the extraction of DNA were obtained from 370 composite beef heifers from two different Brazilian regions (RG and SO Farms) which were distributed into six breed compositions (A-F; Table 1), based on the percentage contribution of cattle breeds of Zebu origin, those adapted to tropical conditions, or British European or Continental European breeds. 


\begin{tabular}{|c|c|c|c|}
\hline \multirow[t]{2}{*}{ Breed composition } & \multicolumn{2}{|c|}{$\mathrm{N}$} & \multirow[t]{2}{*}{ Origin } \\
\hline & RG & SO & \\
\hline A & 2 & 20 & $25 \%$ Zebu x $25 \%$ Adapted $\times 25 \%$ British $\times 25 \%$ Continental \\
\hline B & 31 & 7 & $25 \%$ Zebu $\times 50 \%$ Adapted $\times 25 \%$ Continental \\
\hline $\mathrm{C}$ & 51 & 50 & $25 \%$ Zebu x $50 \%$ Adapted $\times 25 \%$ British \\
\hline $\mathrm{D}$ & - & 98 & $25 \%$ Zebu x $50 \%$ Adapted x $25 \%$ British ( $2^{\mathrm{a}}$ geração) \\
\hline E & 10 & 48 & $50 \%$ Zebu x $50 \%$ Continental \\
\hline $\mathrm{F}$ & 53 & - & $50 \%$ Zebu x $50 \%$ British \\
\hline
\end{tabular}

\section{Genotyping}

Genomic DNA was extracted from the blood samples using the extraction method and precipitation from $\mathrm{NaCl}$ solution described by Olerup and Zetterquist (1992). Based on the polymorphism results obtained with single-strand conformation polymorphism for the LHR (Milazzotto, 2001) and FSHR (Campagnary, 2002) genes, two fragments of interest were selected (Table 2) for polymerase chain reaction (PCR)-RFLP analysis.

\section{Table 2. Description of the restriction fragment length polymorphism (RFLP) markers analyzed.}

\begin{tabular}{lccclc}
\hline Gene & Nature & Chromosome & Exon & Sequence & Reference \\
\hline LHR & RFLP HhaI & 11 & 11 & $\begin{array}{l}\text { F: CAAACTGACAGTCCCCCGCTTT } \\
\text { R: CCTCCGAGCATGACTGGAATGGC }\end{array}$ & Lussier et al., 1995 \\
FSHR & RFLP AluI & 11 & 10 & $\begin{array}{l}\text { F: CTGCCTCCTCAAGGTGCCCTC } \\
\text { R: AGTTCTTGGCTAAATGTCTTAGGGGG }\end{array}$ & Houde et al., 1994 \\
\hline
\end{tabular}

$\mathrm{F}$ (forward) = 5'-3' direction; R (reverse) = 3'-5' direction; LHR = luteinizing hormone receptor; FSHR = folliclestimulating hormone receptor.

The amplification reactions were performed in an MJ Researcher ${ }^{\circledR}$ model PTC-100 (Programmable Thermal Controller) thermocycler, following the time and temperature conditions of each cycle proposed by Milazzotto (2001) for LHR and by Campagnary (2002) for FSHR. Each PCR product was carried out with about 200 ng DNA, in a final reaction volume of $25 \mu \mathrm{L}$, containing 10X PCR buffer (20 mM Tris-HCl, $\mathrm{pH} 8.4,50 \mathrm{mM} \mathrm{KCl}), \mathrm{MgCl}_{2}(3.5 \mathrm{mM}$ for LHR; $2.0 \mathrm{mM}$ for FSHR), $0.5 \mathrm{mM}$ of each deoxynucleoside triphosphate, $0.4 \mu \mathrm{M}$ of each one of the primers and 1 unit Taq DNA polymerase.

The products of the amplifications were then digested with specific restriction enzymes for each marker where the solution was incubated at $37^{\circ} \mathrm{C}$ for $3 \mathrm{~h}$. The resulting fragments were separated by electrophoresis at $65 \mathrm{~V}$ on a $1.5 \%$ agarose gel, stained with ethidium bromide $(5 \mu \mathrm{g} / \mathrm{mL})$, into a $1 \%$ Tris-borate-EDTA buffer, being later evaluated in a Scanner Laser (Fujifilm Fla 3000G) under excitation at $520 \mathrm{~nm}$ and emission at $580 \mathrm{~nm}$. A DNA standard (100-bp DNA ladder; Life Technologies ${ }^{\circledR}$ ) was used in each gel for determination of the size of the fragments, where the genotypes were identified by the absence or presence of the restriction site recognized by the restriction enzymes.

\section{Data analysis}

To evaluate the genetic structure of the population studied, as well as of each breed 
composition, allelic and genotypic frequencies were determined by allelic count and by the count of the different genotypes, respectively (Weir, 1996), for both genes studied.

To show the involvement of the molecular results in the interesting characteristic of sexual precocity, the production data were linked to the diagnosis of pregnancy by rectal palpation at first breeding probability of pregnancy (PP) analyzed as a binary trait, with a value of 1 (success) for the pregnant heifers and of 0 (failure) assigned to those not pregnant.

The following variables were included on the analysis model: genotypic effects for both genes studied, or the haplotype effects (for each genotypic single combination considering both loci analyzed), source farm, breed composition within the source farm, and the covariable weight adjusted to the 390 days of age (PES390) (linear and quadratic effects), added to the residual effect. The PES390 which was calculated from the weight obtained from each animal between the 360 and 420 days of age was included in this analysis, because body weight is one of the factors that affect the puberty event.

General linear models were used by the PROC GENMOD from the Statistical Analysis System version 8.0 (SAS Institute, Inc., 2000), allowing the binomial distribution with the function of logistic connection. The verisimilitude ratio test was used for evaluating the effect of the RFLP (LHR and FSHR) markers on the event of PP, considering the values of $\mathrm{P}<0.05$ to be significant. Forty-one animals were excluded from this analysis, taking into consideration that all the tested subclasses would show the information 0 and 1 for PP, reducing the total population from 370 to 320 animals.

The effect of the identified genotype for LHR and FSHR genes on PP was calculated using the following statistical model:

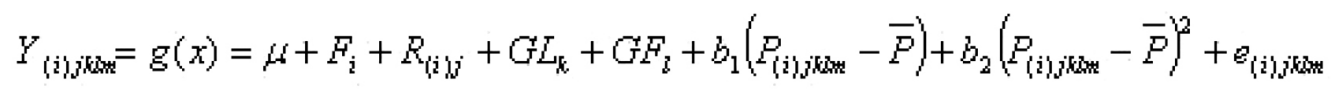

where $\mathrm{Y}_{(i) j k l m}$ represents the characteristic (PP) from the (i)jklm ${ }^{\text {th }}$ animal; $\mathrm{g}(\mathrm{x})$, the connection function (logistic); $\mu$ represents the ratio of the characteristic of the population; $\mathrm{F}_{i}, \mathrm{R}_{(i) j}, \mathrm{GL}_{k}$, $\mathrm{GF}_{l}$, the fixed effects associated with the $\mathrm{i}^{\text {th }}$ farm, $\mathrm{j}^{\text {th }}$ breed composition niche inside the farm, $\mathrm{k}^{\text {th }}$ LHR genotype, $\mathrm{l}^{\text {th }}$ FSHR genotype, $\mathrm{b}_{1}$ and $\mathrm{b}_{2}$, linear and quadratic coefficients of the adjusted weight at the 390th day of age, included in the model as a covariable; $\mathrm{P}_{(i) j k l m}$ is the adjusted weight at the 390th day of age of the (i)jklm ${ }^{\text {th }}$ animal; $\bar{P}$ is the ratio of the adjusted weight at the 390th day of age; $\mathrm{e}_{(i j) \mathrm{klm}}=$ random error effect associated with the (i)jklm ${ }^{\text {th }}$ observation.

The haplotype effects on PP were also observed, adopting the following statistical model:

$$
Y_{j i k}=g(x)=\mu+F_{i}+H_{j}+b_{1}\left(P_{i j k}-\bar{P}\right)+b_{2}\left(P_{i j k}-\bar{P}\right)^{2}+e_{i j k}
$$

where $\mathrm{Y}_{i j k}$ represents the characteristic PP of the $i j \mathrm{k}^{\text {th }}$ animal; $\mathrm{g}(\mathrm{x})$, the connection function (logistic); $\mu$ represents the ratio of the characteristic of the population; $\mathrm{F}_{i}, \mathrm{H}_{j}$, the fixed effects associated with the $\mathrm{i}^{\text {th }}$ farm, $\mathrm{j}^{\text {th }}$ haplotype; $\mathrm{b}_{1}$ and $\mathrm{b}_{2}$, the linear and quadratic coefficients of the adjusted weight to the 390th day of age, included in the model as a covariable; $P_{i j k}$ is the adjusted weight to the 390 th day of age of the $\mathrm{ijk} \mathrm{k}^{\text {th }}$ animal; $\bar{P}$ is the ratio of the adjusted weight of the 390 th day of age; $e_{i j k}=$ random error effect associated with the $\mathrm{ij} \mathrm{k}^{\text {th }}$ observation. 


\section{RESULTS AND DISCUSSION}

The PCR-RFLP analysis allows us to identify the point mutations for LHR and FSHR genes as described by Milazzotto (2001) and Campagnari (2002) (Figure 1).

Figure 1 shows a molecular weight marker on a scale of $100 \mathrm{bp}$; ND1 - undigested product of LHR (303 bp); TT (303 bp); CT (303 and 155/148 bp); CC (155/148 bp); ND2 - undigested product of FSHR (306 bp); GG (193 and 63/50 bp); CG (243/193 and 63/50 bp); CC (243 and $63 \mathrm{bp).}$

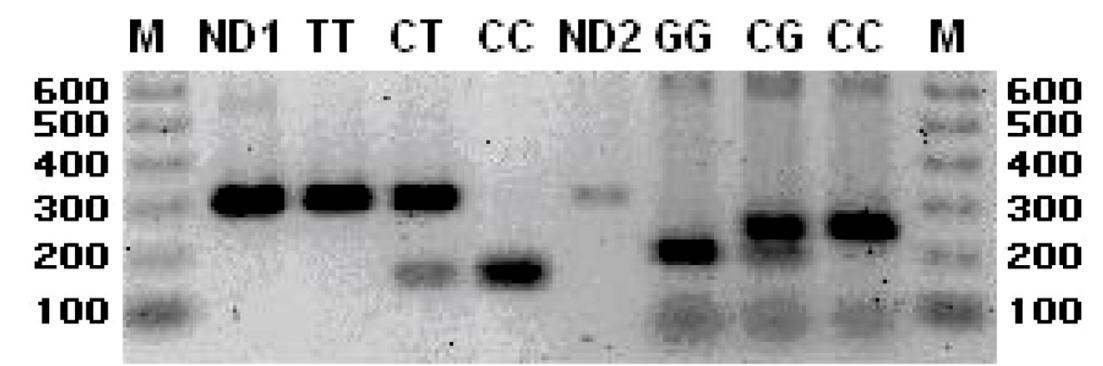

Figure 1. Electrophoresis on $1.5 \%$ agarose gel, stained with ethidium bromide showing the standard fragments of the amplification products (ND1 and ND2) and the products of the digestion of the genes LHR (TT, CT and CC) and FSHR (GG, CG and CC) by PCR-RFLP. $\mathrm{M}=$ molecular weight marker.

In this study, a higher frequency of heterozygotes was recorded among all breed compositions for the LHR gene (Figure 2), except for the composite heifers B and C, which is an important aspect regarding the hybrid origin of the population studied. Lower values of heterozygotes from 0.430 and 0.174 were found by Milazzotto (2001) and Carvalho et al. (2004) for Nellore females, respectively.

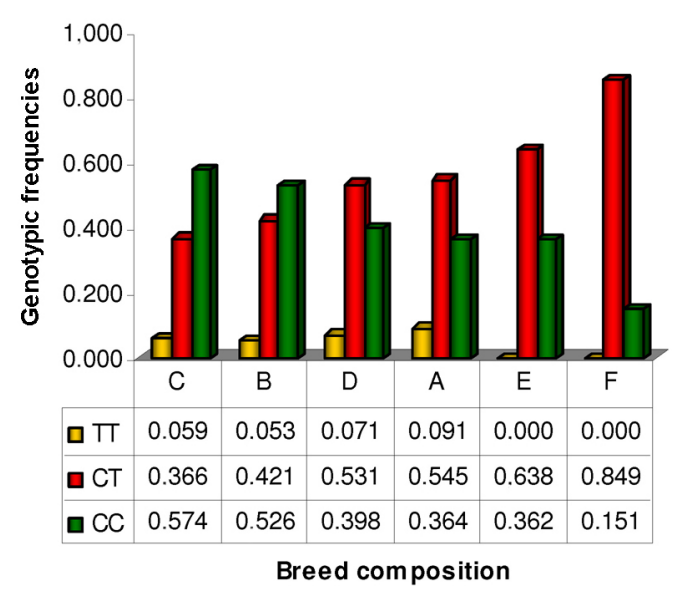

Figure 2. Genotypic frequencies for LHR gene in European-Zebu composite beef heifers of different breed compositions. 
For FSHR, a higher frequency of heterozygotes was recorded in all breed compositions examined (Figure 3). For Nellore breeding, the frequency of heterozygotes reported by Campagnari (2002) was lower than the results obtained for the females F1 (E and F) studied here.

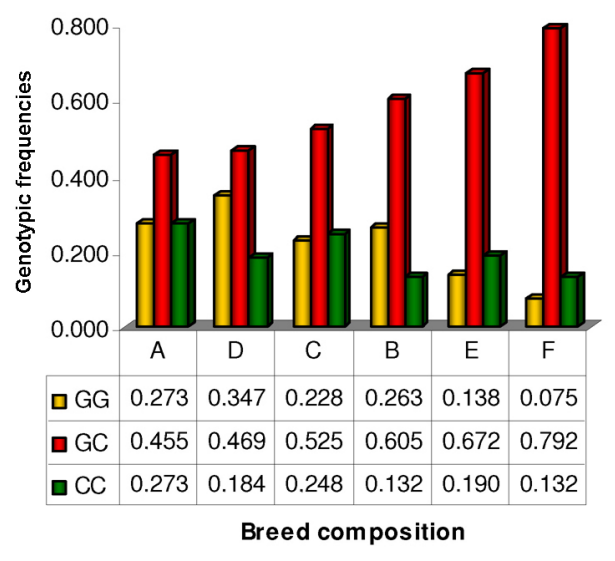

Figure 3. Genotypic frequencies for FSHR gene in European-Zebu composite beef heifers of different breed compositions.

The identification of the genotypes by RFLP, including the heterozygous ones, which enabled the assessment of the genotypic and allelic frequencies, allows us to indicate the study of the genetic markers for LHR and FSHR in further investigations aimed at the evaluation of the genetic structure in other cattle populations, as confirmed by Marson et al. (2005) in this same population.

The general pregnancy rate observed in the composite heifer population studied was $63.5 \%$, a very interesting result, considering the average age of these females at their first breeding (13.5 months). The heterozygous heifers CT and CG showed a pregnancy rate of 67 and $66 \%$, while the homozygous ones TT and GG showed rates of 65 and $58 \%$ and the homozygous ones CC of 58 and 64\% for the LHR and FSHR genes, respectively. However, the effect of the LHR gene $(\mathrm{P}=0.9188)$ or even the FSHR gene $(\mathrm{P}=0.8831)$ on the event of pregnancy in the different breed compositions was not confirmed by the verisimilitude ratio test.

Earlier studies not demonstrated the effect of the LHR genes (Milazzotto, 2001) and the FSHR genes (Campagnari, 2002) on the sexual precocity of Nellore heifers, evaluated by the comparison between the frequencies of precocious or non-precocious females at the age of 14 months, using the $\chi^{2}$ test.

The adjusted weight at 390 days of age (PES390) included in the model as a covariable showed significance for both the linear effect $(\mathrm{P}=0.0417)$ and the quadratic one $(\mathrm{P}=$ 0.0148), confirming the importance of including this source of variation in the model, as body weight is one of the factors that has a large impact on increasing pregnancy rates.

The effect of source farm was noticed on PP $(\mathrm{P}=0.0014)$, the $\mathrm{RG}$ farm showing a higher percentage of precocious females, which means a higher pregnancy rate $(70 \%) \mathrm{com}-$ pared to the SO farm (59\%). This difference may be explained by the fact that all RG heifers were submitted to natural breeding while more than $80 \%$ of the SO heifers were submitted to 
artificial insemination. A significant effect of breed composition on the farm was also observed on PP $(\mathrm{P}=0.0398)$, where this procedure was adopted due to the disproportional breed compositions, at both source farms, showing a superiority in the $\mathrm{F}$ animal composition from the RG farm, with a pregnancy rate of $92 \%$, higher than most of the other compositions analyzed (results not shown).

Although the binomial distribution model proposed was adapted to the available data set, some hypotheses would justify the absence of the marker effects of RFLP observed on sexual precocity. One of them refers to the total number of the animals studied and to the disproportional distribution among the breed compositions in both source farms, even though the precaution was taken in grouping the animals.

Other data that need to be pointed out is that besides LHR and FHSR, other genes equally important in the occurrence of puberty, must contribute for expressing this feature. Therefore, further studies that allow this kind of exploitation could help for the incorporation of the molecular markers in the selection programs regarding the sexual precocity of beef heifers.

In conclusion, it is important to point out again that the assessed inheritability for the age of puberty is considered moderate or even elevated, meaning that this reproductive event is also linked to non-genetic factors. This particularity is also observed in other reproductive characteristics which, differently from the puberty age, show low inheritability, such as birth rate and difficulty at birth (0.19 and 0.18, respectively, according to Splan et al., 1998). These are some of the reasons by which the studies of the genetic polymorphism effects are more frequent on the productive characteristics instead of on the reproductive ones.

Meanwhile, Sutarno et al. (2002) found a significant effect of two mitochondrial DNA regions that showed RFLP in birth rate in both Hereford and Composite ( $1 / 4$ Brahman, Charolais and Holstein x 1/8 Angus and Hereford) bovine females. On the other hand, Almeida et al. (2000) reported important effects of two markers, the LEPSau3AI (RFLP) and the IDVGA-51 (short tandem repeat), for the leptine gene on both the reproductive and productive characteristics, respectively, as time interval between births (IP) and weight at the first birth (PPP) in 5/8 Aberdeen Angus x 3/8 Nellore females. The increase in IP for at least two months of age has been observed by the effect of the two markers, while PPP has been shown to be positively influenced by the LEPSau3AI up to $27 \mathrm{~kg}$. In view of these results, the authors recommend a selection against the RFLP LEPSau3AI marker followed by nutritional supplementation during the pregnancy period.

However, Duarte et al. (2005) did not find any significant effect of microsatellite markers in Brangus Ibagé females (ILSTS027, MBO22 and BM4325) that could be linked to the follicle-stimulating hormone (FSH) genes, sub-unit $\beta$ (FSH $\beta$ ) on PPP, while IP has been proved to be positively influenced by the BM4325 marker. The authors indicate the use of the BM4325 marker for the FSH gene in selection based on markers aimed at improvement of the reproductive performance of the bovine females, suggesting, however, the confirmation of the information obtained within other cattle breeds.

The haplotype CT/CG or double heterozygous is the one that strongly prevailed in the population studied, confirming the higher heterozygous frequency in this hybrid cattle, excluding the $\mathrm{B}$ and $\mathrm{C}$ composite animals which showed a higher incidence of $\mathrm{CC} / \mathrm{CG}$. The heifers identified by the $\mathrm{CT} / \mathrm{CC}$ haplotype and double heterozygous had a higher pregnancy rate of $79 \%(\mathrm{~N}=28)$ and $70 \%(\mathrm{~N}=116)$, respectively. However, the haplotype effects on PP was confirmed in the composite population studied $(\mathrm{P}=0.7886)$. 
The trait PES390 included in the model as a covariable has been significant for the quadratic effect $(\mathrm{P}=0.0273)$, confirming the importance of isolating this variation factor in the model. The effect of the source farm on PP was also confirmed $(\mathrm{P}=0.0004)$, as it was observed in the evaluation of the LHR and FSHR gene effects.

\section{CONCLUSIONS}

PCR-RFLP analysis of LHR and FSHR genes has enabled the genotype identification as well as the heterozygote characterization enhancing our knowledge of the genetic structure of the population studied. The heterozygote frequency was confirmed as being high for both genes which allow the exploitation of these animals in crossbreeding. The genes are suitable for further research in other cattle breeds, for the same purposes.

The effects of the RFLP studied on sexual precocity were not confirmed here for LHR and FSHR genes with regard to sexual precocity, characterized by the probability of pregnancy at first breeding. These results suggest that the selection of precocious heifers based on their genotypic information for the genes examined here is not justified in breeding programs for the composite European-Zebu population studied.

The use of molecular markers for characterizing the heterozygote frequency in hybrid populations for identifying the most divergent breeds in helping to choose the genetic potentials to be used in crossings must at the same time contribute to the reduction of time spent in the experimental evaluations of the performance prediction.

\section{ACKNOWLEDGMENTS}

Research supported by Fundação de Amparo à Pesquisa do Estado de São Paulo (FAPESP, process 01/00790-4) which made this research possible.

\section{REFERENCES}

Almeida SEM, Machado MSN, Steigleder CS, Gama CL, et al. (2000). Genetic diversity in Brazilian bovine herd based on four microsatellite loci. Genet. Mol. Biol. 23: 347-350.

Campagnari F (2002). Novas variantes moleculares dos genes dos receptores do hormônio liberador de gonadotrofinas (GnRHR) e do hormônio folículo estimulante (FSHR) em fêmeas Bos primigenius indicus (Nelore). M.Sc. thesis, Instituto de Biociências, USP, Botucatu.

Carvalho ME, Figueiredo LGG, Marson EP, Ripamonte P, et al. (2004). Caracterização da heterozigose no gene do receptor do hormônio luteinizante (LHR) em animais da raça Nellore. In: Simpósio da Sociedade Brasileira de Melhoramento Animal. Anais do V Simpósio Nacional da Sociedade Brasileira de Melhoramento Animal (SBMA), Pirassununga, (CD-ROM).

Duarte LB, Moraes JC and Weimer TA (2005). Diversity of microsatellites linked to the FSHb gene, their usefulness for individual identification and association with reproductive performance. Cienc. Rural 35: 145-149.

Hess BW (2002). Strategies to anticipate puberty in beef heifers. VI Curso Novos Enfoques na Produção e Reprodução de Bovinos, Uberlândia, 118-126.

Houde A, Lambert A, Saumande J, Silversides DW, et al. (1994). Structure of the bovine follicle-stimulating hormone receptor complementary DNA and expression in bovine tissues. Mol. Reprod. Dev. 39: 127-135.

Laster DB, Smith GM, Cundiff LV and Gregory KE (1979). Characterization of biological types of cattle (Cycle II). II. Postweaning growth and puberty of heifers. J Anim. Sci. 48: 500-508.

Lussier JG, Houde A, Ethier J and Silversides DW (1995). Bos taurus luteinizing hormone receptor mRNA. Genebank accession number: U20504. URL: http://www.ncbi.nlm.nih.gov/entrez/query.fcgi?db=Nucleotide.

Marson EP, Ferraz JB, Meirelles FV, Balieiro JC, et al. (2005). Genetic characterization of European-Zebu composite 
bovine using RFLP markers. Genet. Mol. Res. 4: 496-505.

Milazzotto MP (2001). Mutações no gene do receptor do hormônio luteinizante (LHR) bovino e associação com precocidade sexual em fêmeas Bos primigenius indicus (Nellore). M.Sc. thesis, Instituto de Biociências, Universidade Estadual Paulista, Botucatu.

Olerup O and Zetterquist H (1992). HLA-DR typing by PCR amplification with sequence-specific primers (PCR-SSP) in 2 hours: an alternative to serological DR typing in clinical practice including donor-recipient matching in cadaveric transplantation. Tissue Antigens 39: 225-235.

SAS Institute Inc. (2000). User's guide. SAS Institute Inc., Cary.

Splan RK, Cundiff LV and Van Vleck LD (1998). Genetic parameters for sex-specific traits in beef cattle. J. Anim. Sci. 76: $2272-2278$.

Sutarno, Cummins JM, Greeff J and Lymbery AJ (2002). Mitochondrial DNA polymorphisms and fertility in beef cattle. Theriogenology 57: 1603-1610.

Tambasco DD, Alencar MM, Coutinho LL, Tambasco AJ, et al. (2000). Molecular characterization of a Nellore beef cattle sample using microsatellites and candidate genes. Rev. Bras. Zootec. 29: 1044-1049.

Weir BS (1996). Genetic data analysis II - methods for discrete population genetic data. Sinauer Associates, Sunderland. 